\title{
EFFECT OF FLOOD ON STUDENTS DURING COVID-19 PANDEMIC
}

\author{
Phuloma Daimary \\ Alumna, Tezpur University, Assam, India
}

\begin{abstract}
Flood is a natural disaster that disrupts human lives in all spheres. Along with Covid-19 pandemic in 2020, the students living in annually flood affected areas face multiple challenges in continuing their education amidst flood and the pandemic. The present paper is designed to study the effects of flood on students during covid-19 pandemic and after re-opening of schools. The study is conducted using self designed interview schedule on 100 students of class $I X$ and $X$ from annually flood affected regions of Baksa district. The findings of the study reveal that students faced many problems like health problems, damages of homes and properties, problems in fulfilling basic needs, etc. along with many educational problems during annual flood of 2020 amidst covid-19 pandemic.
\end{abstract}

Key words: flood, covid-19, students, education.

Cite this Article: Phuloma Daimary, Effect of Flood on Students during Covid-19 Pandemic, International Journal of Management, 11(12), 2020, pp 436-442. http://iaeme.com/Home/issue/IJM?Volume=11\&Issue=12

\section{INTRODUCTION}

Natural disaster like flood adversely affect all lives and both natural and man-made resources thereby hindering the social and economic welfare. People living in annually flood affected areas are more vulnerable to social and economic losses. The damages caused by flood are to such an extent that it affects the normal lives of people even after the flood. Assam is a northeastern state of India that witness monsoon flood every year. However Assam flood 2020 was more terrific as it coincided with Covid-19 pandemic. Along with socio-economic losses, health is more vulnerable. As of October, 2020, the floods affected over five million people, claiming the lives of 123 people, with an additional 26 deaths due to landslides, 5474 villages were affected and over one hundred and fifty thousand people found refuge in relief camps. (2020 Assam floods, Wikipedia).

Education is an essential factor of social development which is directly affected by flood. Flood causes infrastructural damages including classrooms, laboratories, libraries, etc. thereby disrupting educational activities in the educational institutions. It also affects students' lives thereby affecting their education. With already shutting down of educational institutions due 
to covid-19 pandemic, education is more affected due to flood for continuing education after re-opening of schools due to the damages caused by flood.

\section{REVIEW OF LITERATURE}

P.V. \& Subudhi (2020) found that flood has psychological and educational impact on students. Chaudhary \& Tamsini (2017) found that due to flood, schools remain closed, infrastructures are damaged and student drop out rises finally affecting the performance of the students. Espaldon, et. al. (2016), found that flood caused disruption of classes, physical damage, and many other problems that interrupted the delivery of educational services which affected students attendence and performance. Mudavanhu (2014), revealed that flood disasters cause disruption in childrens' learning in school and other problems like loss of contact hours, high rates of absenteeism, etc. that affect the quality education. Abbasi \& Shaukat (2013), revealed that floods inflict heavy damage to infrastructure of educational institutions and many educational institutions located in flood affected areas are used as shelter homes resulting in suspension of all activities of the educational institutions including regular classes for a month or more. Hence, students lost interest in studies and perform poorly in examinations.

\section{OBJECTIVES OF THE STUDY}

- To study the effects of flood on students during covid-19 pandemic.

- To study the effects of flood on re-opening of schools.

\section{NEED AND SIGNIFICANCE OF THE STUDY}

Annual flooding in Assam cause damages to properties like bridges, government buildings, roads, schools, and peoples' houses. These damages hamper the development of the state in all spheres. Moreover, it also poses many challenges before the state. One of such challenges is educational challenges. Due to flood, the functioning of educational institutions is disturbed. Schools have to be closed either due to flooding of the school campus or as schools are being used as flood relief camps. Moreover students too face multiple educational challenges due to flood every year. Henceforth, there is a need to study the effects of flood on students in order to prepare the schools to meet the challenges.

\section{METHODOLOGY}

Method of the study: Descriptive survey method is used in the study.

Area of the study: The area of study is Baksa district, an administrative district in Bodoland Territorial Region of the northeastern state of Assam in India.

Sample of the study: 100 students (studying in class IX and X) in 5 government schools located in flood affected regions of Baksa district of Assam were selected through simple random sampling for the study.

Tool used in the study: Interview schedules consisting of both open and closed ended questionnaires designed by the researcher is used in the study for data collection.

Procedure: The researcher visited the selected schools after re-opening of the schools. 13 students, 22 students, 26 students, 19 students and 20 students were interviewed from school 1, school 2, school 3, school 4, and school 5 respectively. Then the data was computed and analyzed. 


\section{DATA ANALYSIS AND INTERPRETATION}

Table 1 Health problems encountered by students during flood

\begin{tabular}{lcc}
\hline Parameters & Frequency & Percentage \\
\hline $\begin{array}{l}\text { Students/family members } \\
\text { tested positive for Covid-19 }\end{array}$ & 22 & $\mathbf{2 2 \%}$ \\
$\begin{array}{l}\text { Students/family members suffering } \\
\text { from water borne diseases }\end{array}$ & 49 & $\mathbf{4 9 \%}$ \\
$\begin{array}{l}\text { Injury among students/ family members } \\
\text { due to flood }\end{array}$ & 10 & $\mathbf{1 0 \%}$ \\
\begin{tabular}{l} 
Deaths among students/ family members \\
\multicolumn{1}{c}{$\sum$ (Mean)= }
\end{tabular} & $\mathbf{2 1}$ & $\mathbf{3 \%}$ \\
\hline
\end{tabular}

Flood has a huge impact on people's health. Flood can cause several health risks like injury, drowning, water borne diseases and many communicable diseases. With covid-19 pandemic, people in flood affected regions during 2020, are more vulnurable to health crisis. Following Covid-19 protocol and maintaining social distancing in flood relief camps are also difficult.

Table I. shows students responses towards health problem encoutered by them during flood amidst Covid-19 pandemic. 22\% students reported they or their family members tested positive for Covid-19. The number of students/family members suffering from water borne diseases is reported to be $49 \%$. $10 \%$ students reported injury among them or family members due to flood. $3 \%$ students reported death among family members due to flood. The mean of health problems encountered by students during flood is 21 . From table I, if we compare the health problems encountered by students during flood, it can be observed that the number of students/family members suffering from water borne diseases is reported to be highest compared to other problems.

Table 2 Damages caused due to flood

\begin{tabular}{lcc}
\hline Parameters & Frequency & Percentage \\
\hline Damages of house & 23 & $\mathbf{2 3 \%}$ \\
Damages of agricultural lands & 60 & $60 \%$ \\
Damages of school infrastructure & 42 & $42 \%$
\end{tabular}

$\sum($ Mean $)=$

41.66

Infrastructural damage and damage to property are common in annually flood affected regions resulting to economic crisis like poverty which in turn affect student's education. Table II shows damages reported by students due to flood. $23 \%$ students reported damages of house, $60 \%$ students reported damages of agricultural lands and $42 \%$ students reported damages of school infrastructure due to flood. The mean of damages caused due to flood is found to be 41.66 .

From table II, if the parameters of damages caused due to flood is compared it can be observed that the damages of agricultural land reported by students is highest, i.e., $60 \%$. 
Agriculture being the sole source of income in rural areas, these damages can lead to poverty and in turn affect students education. Due to poverty students absenteeism may increase or students may also drop out as they may be engaged in other works to generate income for the family.

Table 3 Problems encountered by students in fulfilling basic needs and facilities

\begin{tabular}{lcc}
\hline Parameters & Frequency & Percentage \\
\hline Students living in relief camps & 64 & $64 \%$ \\
Shortage of food and water & 76 & $76 \%$ \\
Lack of sanitation facility & 72 & $72 \%$ \\
Lack of proper medical facilities & 53 & $53 \%$ \\
\hline
\end{tabular}

$$
\sum(\text { Mean })=
$$

66.25

Floods cause problems to families in fulfilling basic needs and facilities as it damages roads and means of communication is interrupted. As a result, there arises problem in regular supply of basic needs like foods, medicines, clothes, etc.

Table III. show problems encountered by students in fulfilling basic needs and facilities during flood. $64 \%$ students reported they lived in relief camps as their houses were damaged by flood or flooded. $76 \%$ students reported they faced shortage of food and water during flood. $72 \%$ students reported that they faced lack of sanitation facility during flood. 53\% students reported that they were deprived of proper medical facilities. The mean of problems encountered by students in fulfilling basic needs and facilities is found to be 66.25. If we compare the parameters of problems encountered by students in fulfilling basic needs and facilities, it can be seen that the number of students reporting shortage of food and water is highest i.e., 76\%. Food and water are basic need needed for survival and if this need is not fulfilled it can affect both physical and emotional health of students. Under such situation, students' education cannot continue in a proper direction.

Table 4 Educational problems encountered by students during flood

\begin{tabular}{|c|c|c|}
\hline Parameters & Frequency & Percentage \\
\hline No classes conducted & 100 & $100 \%$ \\
\hline $\begin{array}{l}\text { No learning environment at } \\
\text { home/ relief centers }\end{array}$ & 71 & $71 \%$ \\
\hline $\begin{array}{l}\text { No learning resources (textbooks, } \\
\text { notebooks, etc.) }\end{array}$ & 48 & $48 \%$ \\
\hline No e-learning resources & 53 & $53 \%$ \\
\hline Lack of motivation & 31 & $31 \%$ \\
\hline
\end{tabular}


Table IV. show educational problems encountered by students during flood. $100 \%$ students reported that no classes were conducted during flood. This was because schools were closed as they were flooded or used as flood relief centers. $71 \%$ students reported that there existed no learning environment at home or in relief centers. $48 \%$ students reported that they had no access to learning resources like textbooks and other materials as it was washed away or damaged by flood or they could not carry it to relief centers. 53\% students reported that they did not have access to e-learning resources like smart phones, good internet connection, etc. $31 \%$ students reported that they faced lack of motivation to study during flood. The mean of educational problems encountered by students during flood is 60.6. From the table, it can be observed that the number of students reporting that no classes were conducted during flood is highest, i.e., $100 \%$ as compared to the other educational problems reported by the students.

Table 5 Challenges encountered after re-opening of schools

\begin{tabular}{lcc}
\hline Parameters & Frequency & Percentage \\
\hline Fear of contracting covid-19 & 44 & $44 \%$ \\
Lack of time to complete lessons & 48 & $48 \%$ \\
Change in class timing & 69 & $69 \%$ \\
Poor classroom facility & 63 & $63 \%$ \\
Poor sanitation facility & 51 & $51 \%$ \\
Poor motivation & 19 & $19 \%$ \\
\hline \multicolumn{1}{c}{$\sum($ Mean $)=$} & & 49 \\
\hline
\end{tabular}

Table V. shows challenges encountered by students after re-opening of schools. $48 \%$ students reported lack of time to complete lessons. $69 \%$ students reported change in class timing and it is challenging for them to cope with the new class timings. $63 \%$ students reported poor classroom facility as flood caused infrastructural damages. 51\% students reported poor sanitation facility in schools. 19\% students reported poor motivation as they stayed away from studies for many months during flood. The mean of challenges encountered by students after re-opening of schools is found to be 49 .

\section{FINDINGS}

The findings of the study reveal due to flood students encountered health problems, damages of homes and properties, problems in fulfilling basic needs and facilities and problems in their studies. After re-opening of schools, students faced problems such as lack of time to complete lessons, poor classroom facility and poor motivation.

\section{CONCLUSION}

Floods make a significant impact in all spheres of human lives thereby disrupting progress of human society. But with covid-19 pandemic, the annual flood of 2020 was more devastating. The education of the students is disrupted and students have to face many challenges even after re-opening of the schools. Therefore, there is a need to make education disaster resistant. Necessary steps need to be taken to make the schools located in annually flood affected areas 
prepared to face the challenges brought about by the floods. Maximum educational support should be given to students of flood affected areas.

\section{REFERENCES}

[1] Abbasi, S.S., \& Shaukat, B. (2013). The effects of 2010 flood on educational institutions and children schooling in Khyber Pukhtoonkhwa: A study of Charsadda and Swat districts. International Journal of Environment, Ecology, Family and Urban Studies, 3(3), 112.Retrieved from: http://www.tjprc.org/publishpapers/2-56-1374496183-

1.The $\% 20$ effects $\% 20$ of $\% 20$.full.pdf

[2] Akelo, S. (2014). Effects of floods on students' access to secondary education in Nyando district, Kisumu County, Kenya. (master's thesis). University of Nairobi. Retrieved from: http://erepository.uonbi.ac.ke/handle/11295/76382

[3] Ardales, G.Y., Espaldon, M.V.O., Lasco, R.D., Quimbo, M.A.T., \& Zamora. O.B. (2016). Impacts of floods on public schools in the municipalities of Los Banos and By, Laguna, Phillipines. Journal of Nature Studies,15(1), 19-40.Retrieved from: https://www.researchgate.net/publication/320490757

[4] Bubeck, P., Otto, A. \& Weichselgartner, J. (2017). Societal impact of flood hazards. Oxford Research Encyclopedia of Natural Hazard Science. doi.

0.1093/acrefore/9780199389407.013.281

[5] Chaudhary, G. \& Timsina, T.P. (2017). Impact of Flood on Performance of Students The Case of Secondary School Students in Jaleshwor Municipality, Mahottari. Journal of Advanced Academic Research, 4(1), 12-26.Retrieved from: https://www.nepjol.info/index.php/JAAR/article/view/19515

[6] Conteh, I.K. (2015). Natural hazards and education: The impact of floods on primary school education in Zambia. [e-book]. Retrieved from:

https://www.semanticscholar.org/paper/Natural-hazards-and-education-\%3A-the-impact-ofon-in-Conteh/04a846ff784854767545be9a7d432ce0a9d1ee68

[7] Deka, P.P. (2015). A Study on Flood Disaster in Assam: Threats and measures. Paripex: Indian Journal of Research, 4(7), 315-317.Retrieved from:

https://www.worldwidejournals.com/paripex/recent_issues_pdf/2015/July/July_2015_143832 0065_104.pdf

[8] Greeshma, P.V., \& Subudhi, C. (2020). Psycho-social and educational impact of flood among school going children. Journal of Social Welfare and Management, 12(1), 15-24. doi: http://dx.doi.org/10.21088/jswm.0975.0231.12120.2

[9] Guiteras, R., Jina, A.S., Lopez, K., Mobarak, A.M., \& Vargas, C. (2014). The effects of flood on educational attainment for young children in Bangladesh. Retrieved from: https://gradschool.umd.edu/sites/gradschool.umd.edu/files/uploads/claudiavargas.pdf

[10] Kousky, C. (2016). Impacts of natural disasters on children. Spring, 26(1), 73-92. Retrieved from: https://files.eric.ed.gov/fulltext/EJ1101425.pdf

[11] Kumar, A.R., \& Raghav, A.A. (2018). A Case study on the flood situation of Assam state. International Research Journal of Engineering and Technology, 5(5), 4192-4194. Retrieved from: https://www.irjet.net/archives/V5/i5/IRJET-V5I5894.pdf 
[12] Mudavanhu, C. (2014). The impact of flood disasters on child education in Muzarabani district. Jamba: Journal of Disaster Risk Studies, 6(1), 1-8. doi:10.4102/jamba.v6i1.138

[13] Singh, R.B., Pandey, B.W., \& Prasad, A.S. (2014). Living with flood and sustainable livelihood development in lower Brahmaputra river basin, Assam. Indian Streams Research Journals, 4(4), 1-9. Retrieved from: https://www.researchgate.net/publication/310951294

[14] Vranda, N.M., \& Sekar, K. (2011). Psychosocial impact of flood on children: A qualitative study. The Odisha Journal of Psyciatry, 29-37. Retrieved from: https://www.researchgate.net/publication/335377778

[15] 2020 Assam floods, Wikipedia. Retrieved from: https://en.wikipedia.org/wiki/2020_Assam_floods Retrieved on: 4 Dec, 2020. 